\title{
FERTILIZATION MODEL FOR FLUE-CURED TOBACCO (NICOTIANA TABACUM L.) IN SOUTHWEST CHINA
}

\author{
WANG, S. N. ${ }^{1,2}-$ CHENG, J. K. ${ }^{3,4}-$ LIAO, Y. C. ${ }^{*}$ \\ ${ }^{I}$ College of Agronomy, Northwest A\&F University, Yangling, Shaanxi 712100, PR China \\ ${ }^{2}$ School of Biological and Chemical Engineering, Panzhihua University, Panzhihua, Sichuan \\ 617000, PR China \\ ${ }_{3}^{3}$ School of Mathematics and Computer Science, Panzhihua University, Panzhihua, Sichuan \\ 617000, PR China \\ ${ }^{4}$ College of Software, Shanxi Agricultural University, Jinzhong, Shanxi 030801, PR China \\ ${ }^{*}$ Corresponding authors \\ e-mail: yunchengliao@163.com \\ (Received $18^{\text {th }}$ Mar 2020; accepted $20^{\text {th }}$ Aug 2020)
}

\begin{abstract}
The fertilization model is an important breakthrough in the field of nutrient management for high quality crop production. However, there are few studies on the flue-cured tobacco fertilization model. In this study eight plots were selected, for use in a fertilization experiment to determine the optimal nitrogen, phosphorus and potassium fertilizer application amounts for flue-cured tobacco planting in the Southwest China. Based on parameters such as the nutrient requirements, fertilizer utilization rate, and soil nutrient correction coefficient of flue-cured tobacco, the curves of $\mathrm{N}, \mathrm{P}_{2} \mathrm{O}_{5}, \mathrm{~K}_{2} \mathrm{O}$ and their corresponding nutrient correction coefficients were constructed. We fitted a non-linear curve model using soil parameters, i.e. yield per area, nutrient requirements and fertilizer utilization rate, etc. The result showed that the recommended fertilization models are $\mathrm{N}=0.091 \times Y-149.505 \times \mathrm{S}_{\mathrm{N}}{ }^{0.029} ; \mathrm{P}_{2} \mathrm{O}_{5}=0.072 \times Y-$ $11.595 \times \mathrm{SP}_{\mathrm{P}}{ }^{0.749} ; \mathrm{K}_{2} \mathrm{O}=0.199 \times Y-55.924 \times \mathrm{S}_{\mathrm{K}}{ }^{0.351}$. The validation of the experiments showed that the yield of the flue-cured tobacco reached about $2,700 \mathrm{~kg} \mathrm{ha}^{-1}$. In addition, the recommended amount of fertilization was $30 \%$ less than the conventional fertilizer application. Therefore, the recommended amount will lower the production cost, reduce the environmental pollution caused by excess soil fertility, and promote the sustainable development of flue-cured tobacco planting.
\end{abstract}

Keywords: soil nutrients, fertilizer utilization rate, yield, recommended fertilization, decision model

\section{Introduction}

Plant nutrients are the major components of crop growth, of which nitrogen $(\mathrm{N})$, phosphorus $(\mathrm{P})$ and potassium $(\mathrm{K})$ are considered the most basic elements for agricultural production. Thus, the maintenance of soil fertility is needed for crop productivity (Shen et al., 2010; Yavitt et al., 2011). The reasonable application of nitrogen phosphorus and potassium fertilizers provides the important contribution to increasing yield. To obtain the highest yield, farmers usually use excessive fertilization regardless of the environmental impact (Zhao et al., 2016; Williams et al., 2017). Excess fertilizer will be lost to the environment in various ways, including surface runoff, underground leaching and trace gas emission, causing considerable environmental problems (Pappa et al., 2011; Ahmed et al., 2017; Russo et al., 2017).

An increasing body of evidence based on long-term experiments have shown that environmental pollution from agricultural production caused by excessive fertilization use can be alleviated by changing tillage methods and crop rotation systems (Lehmeier et al., 2013; Sun et al., 2015; Guillaume et al., 2016), as well as by modifying the 
fertilization method and irrigation systems. Gilhespy et al. (2014) showed that different fertilization methods and fertilizer application amounts could change the nitrogen load of paddy fields. Hossain et al. (2018) noted that an appropriate fertilizer-water ratio can improve the physicochemical properties of the soil and increase cucumber yields.

Recently, scientists have conducted many targeted works on nitrogen phosphorus and potassium fertilizers (Subhashini, 2016; Kumaresan et al., 2019; Lisuma et al., 2020). Although most studies provide valuable perspectives on crop growth and development, the conclusions and recommendations obtained have some limitations. For example, the short length of the experimental period limited the possibility of obtaining robust conclusions, making difficult the establishment of appropriate cropping strategies with only few years of experimental data. Thus, strong recommendations for crop management would require a large number of experimental years with time and cost associated. Therefore, the combination of experimental work with the use of crop simulation models may help to overtake this limitation.

Flue-cured tobacco (Nicotiana tobacum L.) is an important cash crop in China. Many applications of flue-cured tobacco in drug resources and food development is being continuously discovered and utilized (Sheets et al., 2016; Crossthwaite et al., 2017). Therefore, high-quality flue-cured tobacco planting has broad prospects (Vann et al., 2013; Amankwa et al., 2014; Shen et al., 2017). The estimate of reasonable amounts of fertilization by constructing a flue-cured tobacco fertilization model through different fertilizing experiments is an important breakthrough in high-quality flue-cured tobacco production (Hu et al., 2018). At present, few studies have reported on flue-cured tobacco fertilization models, and most studies did not use factors such as flue-cured tobacco quality to verify the fertilization models in field experiments.

This study performed fertilization experiments on flue-cured tobacco in a mountainous area of Southwest China. And this study had two main objectives: (1) to determine a rational fertilization amount in flue-cured tobacco planting; (2) to establish fertilization model for flue-cured tobacco and to verify the model.

\section{Materials and methods}

\section{Materials}

\section{Site description}

From 2013 to 2017, eight experimental plots (1-8) in mountainous areas of southwest China were selected for field experiments. In 2018, three representative tobacco plots (I, II, III,) were selected to conduct validation experiments. These plots are located in the Experimental Station of the Yanbian County, Panzhihua City, Sichuan Province $\left(27^{\circ} 05^{\prime} \mathrm{N}\right.$ and $101^{\circ} 46^{\prime} \mathrm{E}, 2097 \mathrm{~m}$ above sea level) (Figure 1).

Our study area belongs to the subtropical dry-hot valley climate, and shows mean annual precipitation of $1065 \mathrm{~mm}$, which is mainly concentrated between June and October. The annual average sunshine duration is $2307 \mathrm{~h}$, and the annual average temperature is $19.2{ }^{\circ} \mathrm{C}$ ( $\mathrm{Li}$ et al., 2018). The soils are Alumi-Ferric Alisols (FAO/UNESCO, 1988). Every experimental plot is flat and inside with uniform fertility. The basic physicochemical properties of the surface soil $(0-20 \mathrm{~cm})$ were measured before the experiment in 2013 (Table 1). 

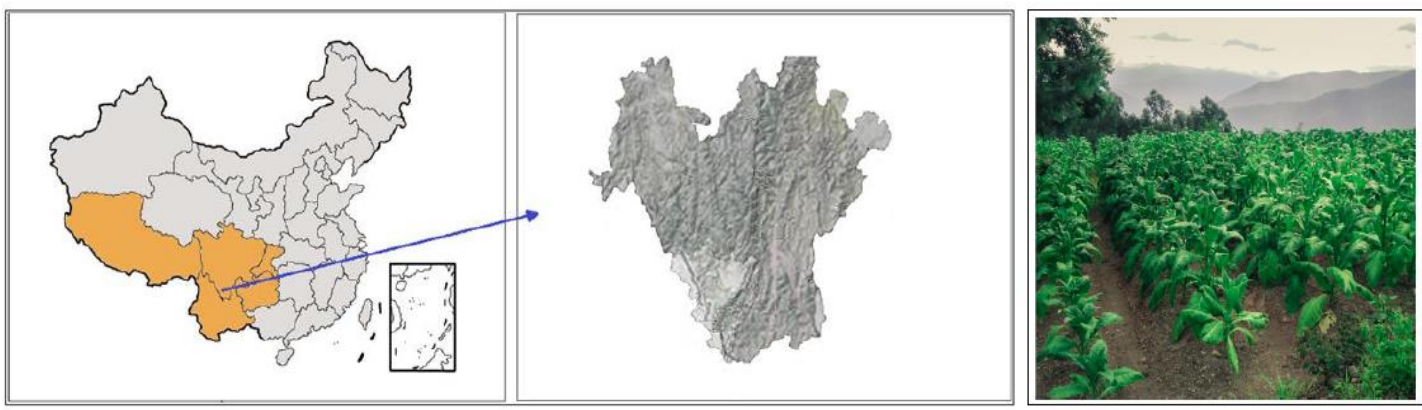

Figure 1. Map of the experimental field in southwest China

Table 1. Initial soil properties of the experiment in Yanbian County during 2013, southwest China

\begin{tabular}{c|c|c|c|c|c|c}
\hline $\begin{array}{c}\text { Experimental } \\
\text { plots }\end{array}$ & $\mathbf{p H}$ & $\begin{array}{c}\text { SOC } \\
\mathrm{g} \mathrm{kg}^{-1}\end{array}$ & $\begin{array}{c}\text { Total N } \\
\mathrm{g} \mathrm{kg}^{-1}\end{array}$ & $\begin{array}{c}\text { Alkali-N } \\
\mathrm{mg} \mathrm{kg}^{-1}\end{array}$ & $\begin{array}{c}\text { Olsen-P } \\
\mathrm{mg} \mathrm{kg}^{-1}\end{array}$ & $\begin{array}{c}\text { Ava-K } \\
\mathrm{mg} \mathrm{kg}^{-1}\end{array}$ \\
\hline 1 & 6.15 & 28 & 1.33 & 83.5 & 2.2 & 142.5 \\
2 & 5.85 & 31.8 & 1.62 & 115.35 & 8.35 & 135.62 \\
3 & 6.51 & 9.58 & 0.85 & 86.7 & 8.53 & 105.28 \\
4 & 6.48 & 25.85 & 1.25 & 95.36 & 2.05 & 138.85 \\
5 & 6.52 & 14.35 & 0.92 & 78.35 & 10.38 & 102.35 \\
6 & 5.72 & 23.35 & 1.38 & 125.32 & 11.24 & 125.18 \\
7 & 6.65 & 13.25 & 1.32 & 92.35 & 12.55 & 123.75 \\
8 & 6.25 & 25.55 & 1.68 & 118.34 & 8.48 & 135.65 \\
\hline
\end{tabular}

SOC was soil organic carbon, Total $\mathrm{N}$ was total nitrogen, Alkali-N was alkali-hydrolyzale nitrogen, Olsen-P was Olsen phosphorus, Ava-K was available potassium

\section{Experimental design}

Seven treatments were conducted using a randomized block design with three replicates. All treatments were applied in every experimental plot (Table 2). The plot size was $77 \mathrm{~m}^{2}(11 \mathrm{~m} \mathrm{x} 7 \mathrm{~m})$. The fertilizer used for the test was calcium ammonium nitrate for agricultural use ( $\mathrm{N}$ content: $\left.155 \mathrm{~g} \mathrm{~kg}^{-1}\right)$, superphosphate $\left(\mathrm{P}_{2} \mathrm{O}_{5}\right.$ content: $\left.160 \mathrm{~g} \mathrm{~kg}^{-1}\right)$ and potassium sulphate $\left(\mathrm{K}_{2} \mathrm{O}\right.$ content: $\left.500 \mathrm{~g} \mathrm{~kg}^{-1}\right)$, of which $70 \%$ was basal fertilizer (applied at the transplanting period), and 30\% was topdressing (applied 20 days after transplanting). The flue-cured tobacco variety used in the experiment was Yunyan87, which was provided by the China Tobacco Import and Export Sichuan Co. Ltd.

Table 2. Application scheme of flue-cured tobacco fertilizer $\left(\mathrm{kg} \mathrm{ha}^{-1}\right)$

\begin{tabular}{c|c|c|c}
\hline Treatments & $\mathbf{N}$ & $\mathbf{P}_{\mathbf{2}} \mathbf{O}_{\mathbf{5}}$ & $\mathbf{K}_{\mathbf{2}} \mathbf{O}$ \\
\hline 1 & 0 & 0 & 0 \\
2 & 0 & 135 & 270 \\
3 & 90 & 0 & 270 \\
4 & 90 & 135 & 0 \\
5 & 60 & 90 & 180 \\
6 & 90 & 135 & 270 \\
7 & 120 & 240 & 360 \\
\hline
\end{tabular}


The experimental flue-cured tobacco was planted with floating seedlings that were transplanted on April $20^{\text {th }}$ of each year, harvest and baking began on July 20, and the harvest ended on September 1st. The field growth period was 130 days, and the management methods for the field tillage were conducted according to the local conventional methods. The experimental plots were ploughed after 15 and 35 days of flue-cured tobacco transplanting, and irrigated when the soil moisture content is less than $60 \%$. When the buds of flue-cured tobacco grow to $4-6 \mathrm{~cm}$, remove the buds and the next 3 leaves. Tobacco leaves were harvested in different plots and uniformly baked before the yield was calculated. Central leaves $(2 \mathrm{~kg})$ with consistent maturity (at leaf positions 8, 9, 10 and 11) were selected from each treatment for the chemical composition analysis. The quality of flue-cured tobacco was evaluated by chemical composition content.

\section{Evaluation criteria for high-quality flue-cured tobacco}

Usually we use the content of chemical composition as the evaluation standard of flue-cured tobacco quality (White et al., 1979). A review of multiple sources of reference data showed that in high-quality flue-cured tobacco leaves, the nitrogen content is $2.5 \%$; the phosphorus content is $0.6 \%$; the higher the potassium content is, the better; the total sugar content is $20 \%$; the reducing sugar content is $15 \%$; the chlorine content is $0.5 \%$; and the nicotine content is $2 \%$ (Sun et al., 2011).

\section{Methods}

The model was developed using Truog-Stanford equation of the nutrient balance method. The equation was that calculated the difference between the amount of fertilizer required by the crop and the amount of fertilizer provided by the soil, and then determined the amount of fertilizer applied to the crop. The core idea is that the nutrients plants need to grow are provided by both soil and fertilizer. Fertilizing is used to supplement the soil nutrient deficiency during crop growth. Only when the nutrient supply and demand balance is reached can the crop achieve the target yield. Therefore, the Truog-Stanford equation mainly involves parameters such as target yield, crops required fertilizer amount, soil fertilizer supply amount, and fertilizer utilization rate. First, the physicochemical properties of the soil had to be accurately measured. The required pattern for the crop fertilizer and the annual yield had to be determined. Then, field experiments were conducted to determine the target yield and determine the type, quantity and ratio of the fertilizer required for the target yield.

\section{Determination of fertilizer utilization rate}

The amount of $\mathrm{N}, \mathrm{P}_{2} \mathrm{O}_{5}$, and $\mathrm{K}_{2} \mathrm{O}$ uptake by flue-cured tobacco in yield per unit area was calculated based on analysis in the field experimental tests of eight experimental tobacco plots and laboratory tests from 2013 to 2017 (Figure $2 A$ ). The $\mathrm{N}, \mathrm{P}_{2} \mathrm{O}_{5}$ and $\mathrm{K}_{2} \mathrm{O}$ fertilizer utilization rates of the 8 experimental plots were calculated according to Equation 1 (Figure 2B). It shows that the average $\mathrm{N}$ utilization rate was $38.21 \%$, and its value varied from $31.95 \%$ to $45.33 \%$; the average phosphorus $\left(\mathrm{P}_{2} \mathrm{O}_{5}\right)$ utilization was $15.58 \%$, with values ranging from $11.87 \%$ to $19.82 \%$; and the average potassium $\left(\mathrm{K}_{2} \mathrm{O}\right)$ utilization rate was $28.28 \%$, with its value varying in the range of $20.65 \%$ to $34.53 \%$. 

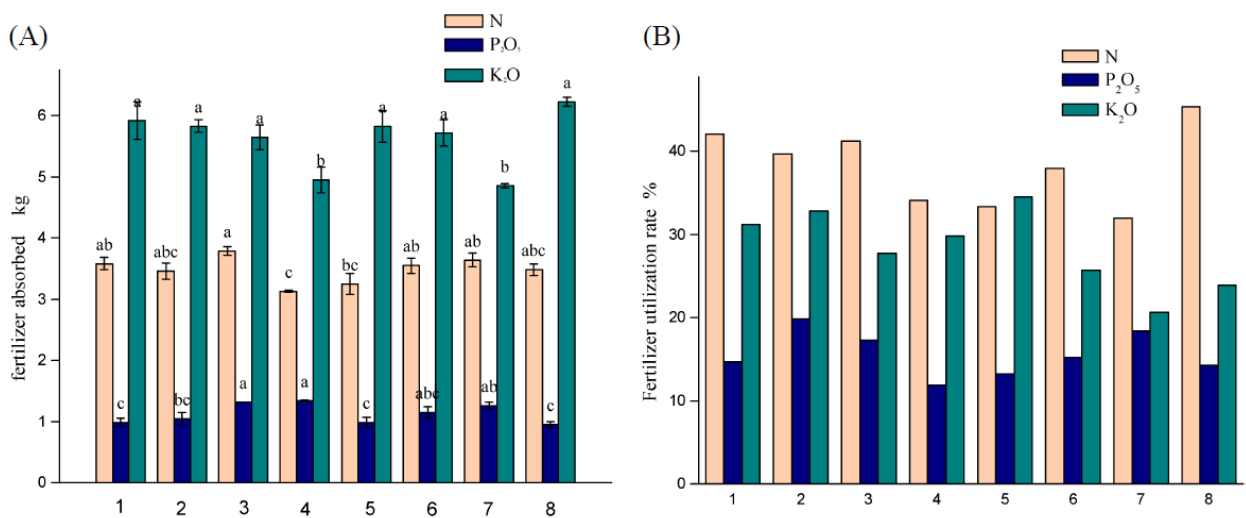

Figure 2. The amount of $\mathrm{N}, \mathrm{P}_{2} \mathrm{O}_{5}$ and $\mathrm{K}_{2} \mathrm{O}$ fertilizer absorbed by per $100 \mathrm{~kg}$ flue-cured tobacco $(A)$ and the fertilizer utilization rate of each experimental plot $(B)$. Different letters within the same column indicated significant differences $(p<0.05)$

$$
R=\frac{A_{1}-A_{O}}{F} * 100 \%
$$

where, $\mathrm{R}$ represents the fertilizer utilization rate; $\mathrm{A} 1$ is the fertilizer absorption amount in fertilization area, and $\mathrm{A} 0$ is the fertilizer absorption amount in 0 fertilization area; $\mathrm{F}$ represents the fertilizer application amount in the experiment.

\section{Calculate the soil fertility correction coefficient}

The soil fertility correction coefficient for each experimental plot was calculated according to Equation 2. It shows that the correction coefficients of the soil Alkali-N, Olsen-P and Ava-K varied significantly, mainly relative to factors such as the soil available nutrient content, soil moisture status, soil types, climatic conditions and growth conditions of the flue-cured tobacco (Figure 3). The correction coefficients for the Alkali-N ranged from $22.25 \%$ to $37.68 \%$ with an average of $29.98 \%$; the correction coefficients for the Olsen-P varied from $35.96 \%$ to $67.39 \%$ with an average of $50.57 \%$; and the correction coefficient for the Ava-K ranged from $27.68 \%$ to $35.95 \%$, with an average of $31.46 \%$.

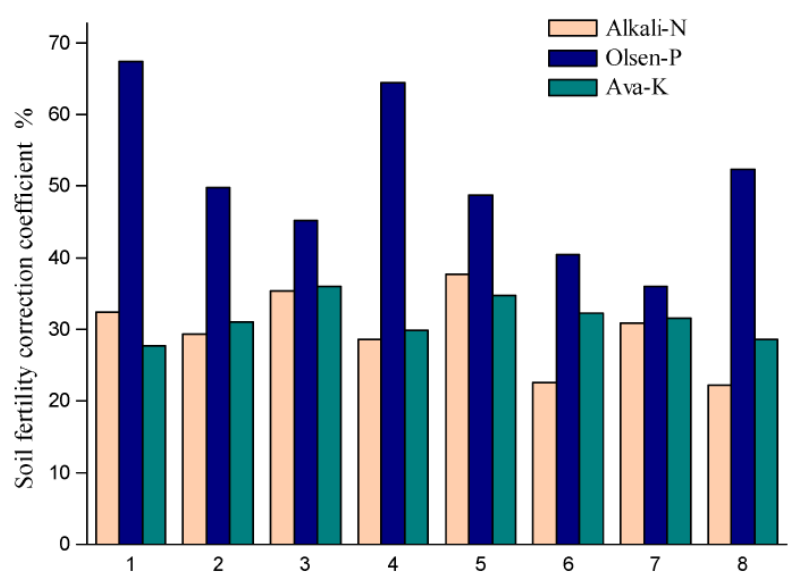

Figure 3. Soil fertility correction coefficient $(B)$ of each experimental plot 


$$
C=\frac{A_{0}}{S * 0.15} * 100 \%
$$

where, $\mathrm{C}$ represents the soil fertility correction coefficient. S represents the soil fertility. 0.15 is the conversion factor of the measured value $\left(\mathrm{mg} \mathrm{kg}^{-1}\right)$ of soil fertility to the potential fertilizer supply amount per hectare of arable soil.

\section{Construction of the recommended fertilization model for flue-cured tobacco}

In this study, we used the soil available fertility content $\left(x, \mathrm{mg} \mathrm{kg}^{-1}\right)$ and the corresponding soil fertility correction coefficient $(y)$ for regression analysis and model fitting to establish the regression equations (Figure 4). As can be seen in Figure 4, with the increase in the Alkali-N, Olsen-P and Ava-K concentrations in the experimental plots, the corresponding correction coefficients all showed a downward trend. The fitting was performed using a Curve model, and the $\mathrm{F}$ test showed that all regression relationships achieved significant levels $(\mathrm{p}<0.05)$.

(A)

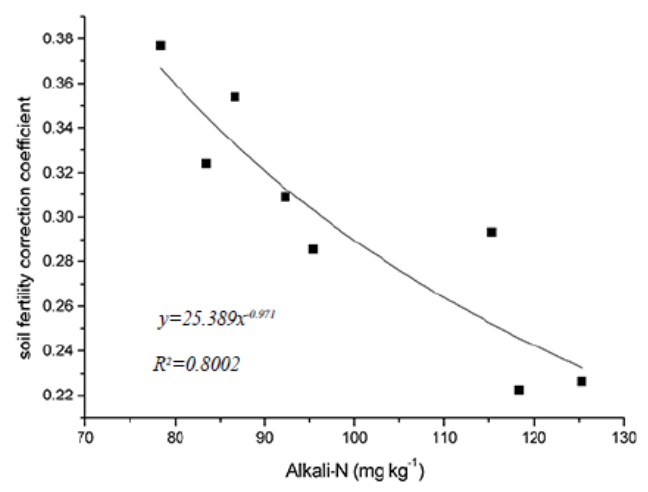

(B)

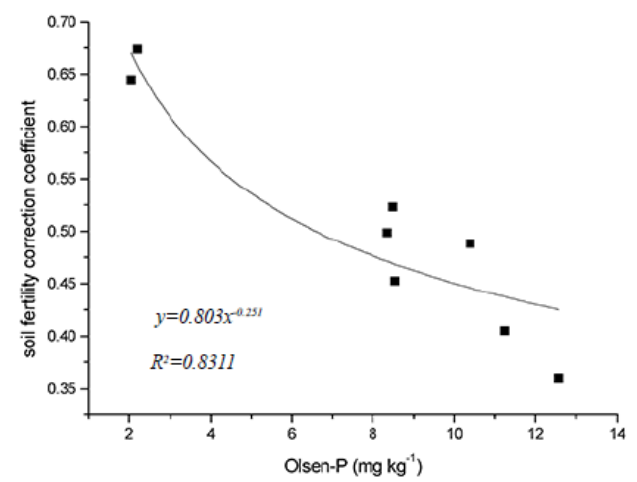

(C)

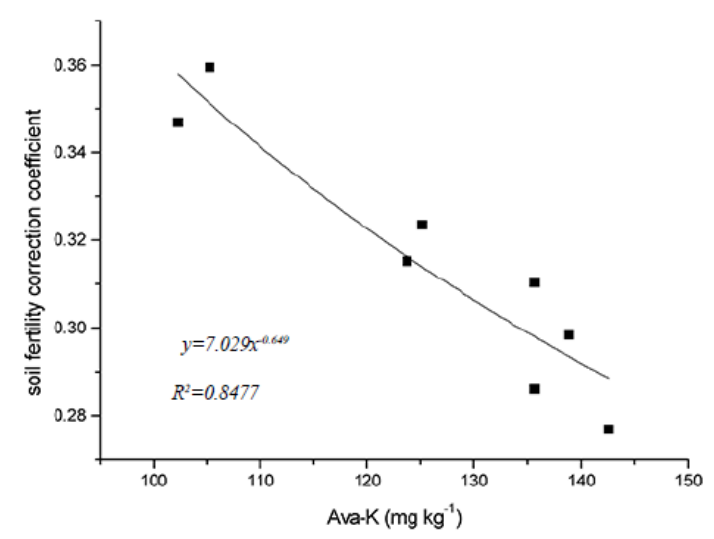

Figure 4. Curve fitting model of Alkali-N (A), Olsen-P (B), Ava-K $(C)$ and soil fertility correction coefficient

The recommended fertilization model of flue-cured tobacco for nitrogen $(\mathrm{N})$, phosphorus $\left(\mathrm{P}_{2} \mathrm{O}_{5}\right)$, and potassium $\left(\mathrm{K}_{2} \mathrm{O}\right)$ fertilizers with different target yields was obtained using the Truog-Stanford Equation 3. 
Fertilizer application amount $($ pure nutrient $)=$

$$
=\frac{\text { Fertilizer requirement }- \text { Soil fertility supply }}{\text { Fertilizer utilization rate }}=\frac{Y * U-S * 0.15 * C}{R}
$$

where: Y represents the target yield, and $U$ stands for the required fertilizer in yield per unit area.

Based on the physicochemical properties of the soil, combined with the soil fertility correction coefficient, nutrient uptake by flue-cured tobacco, fertilizer utilization, etc., the fertilization models were as followed:

$$
\begin{aligned}
& \mathrm{N}=0.091 \times Y-149.505 \times S_{N}{ }^{0.029} \\
& \mathrm{P}_{2} \mathrm{O}_{5}=0.072 \times Y-11.595 \times S_{P}{ }^{0.749} \\
& \mathrm{~K}_{2} \mathrm{O}=0.199 \times Y-55.924 \times S_{K}{ }^{0.351}
\end{aligned}
$$

In the above three models, $\mathrm{N}, \mathrm{P}_{2} \mathrm{O}_{5}$, and $\mathrm{K}_{2} \mathrm{O}$, were the recommended amounts of the nitrogen phosphorus and potassium (pure nutrients) fertilization. $Y$ was the target yield, and $S N, S P$ and $S K$, were the contents of the Alkali-N, Olsen-P, and Ava-K in the soil.

\section{Result and Discussion}

\section{Validation the fertilization model}

In 2018, the verification experiments were conducted in Yanbian County, Panzhihua City. According to the yield and quality conditions of flue-cured tobacco in Panzhihua City over the years, combined with relevant literature and consultation with relevant experts, the target yield of flue-cured tobacco was set at $2,700 \mathrm{~kg} \mathrm{ha}^{-1}$. Based on the studied fertilization models for recommended nitrogen $(\mathrm{N})$, phosphorus $\left(\mathrm{P}_{2} \mathrm{O}_{5}\right)$ and potassium $\left(\mathrm{K}_{2} \mathrm{O}\right)$ fertilization, the recommended fertilization amount at each verification plot was calculated (Table 3).

Table 3. Fertilization verification experiment of flue-cured tobacco in 2018

\begin{tabular}{c|ccc|ccc}
\hline \multirow{2}{*}{$\begin{array}{c}\text { Verification } \\
\text { plot }\end{array}$} & \multicolumn{3}{|c|}{ Original soil-fertility $\left(\mathbf{m g ~ k g} \mathbf{~ k}^{-1}\right)$} & \multicolumn{3}{c}{$\begin{array}{c}\text { The model recommended fertilizer } \\
\text { application (kg ha-1) }\end{array}$} \\
\cline { 2 - 7 } & Alkali-N & Olsen-P & Ava-K & $\mathrm{N}$ & $\mathrm{P}_{2} \mathrm{O}_{5}$ & $\mathrm{~K}_{2} \mathrm{O}$ \\
\hline I & 125.83 & 9.31 & 128.06 & 73.69 & 132.74 & 230.18 \\
II & 72.95 & 16.27 & 82.75 & 76.39 & 100.73 & 273.82 \\
III & 118.37 & 2.53 & 185.5 & 74.00 & 171.16 & 187.52 \\
\hline
\end{tabular}

In this study, we selected $2 \mathrm{~kg}$ of central leaves with consistent maturity from the three validation plots for each chemical composition analysis. The chemical composition and yield of flue-cured tobacco from the three verification plots are shown in Table 4. It shows the chemical component contents of the flue-cured tobacco from each plot were consistent with those of high-quality flue-cured tobacco, and the yield reached the expected target approximately $2,700 \mathrm{~kg} \mathrm{ha}^{-1}$. The recommended amount of fertilization was $30 \%$ less than that of the conventional fertilizer application. Therefore, in the verification plot, the application of $\mathrm{N}$ was $74.00-76.39 \mathrm{~kg} \mathrm{ha}^{-1}$, the application of $\mathrm{P}_{2} \mathrm{O}_{5}$ was $100.73-171.16 \mathrm{~kg} \cdot \mathrm{ha}^{-1}$, and the application of $\mathrm{K}_{2} \mathrm{O}$ was $187.52-273.82 \mathrm{~kg} \mathrm{ha}^{-1}$. The recommended fertilization model is reasonable and feasible for the experimental area. 
Table 4. The chemical composition and yield of flue-cured tobacco from the verification plots

\begin{tabular}{c|c|c|c|c|c|c|c|c}
\hline $\begin{array}{c}\text { Verification } \\
\text { plot }\end{array}$ & $\begin{array}{c}\text { Nitrogen } \\
\%\end{array}$ & $\begin{array}{c}\text { Phosphorus } \\
\%\end{array}$ & $\begin{array}{c}\text { Potassium } \\
\%\end{array}$ & $\begin{array}{c}\text { Total } \\
\text { sugar }\end{array}$ & $\begin{array}{c}\text { Reducing } \\
\text { sugar }\end{array}$ & Chlorine & Nicotine & Yield \\
& $\%$ & $\%$ & $\%$ & $\mathrm{~kg} \mathrm{ha}^{-1}$ \\
\hline I & 2.03 & 0.64 & 2.36 & 19.2 & 14.71 & 0.41 & 1.82 & 2805.5 \\
II & 2.11 & 0.52 & 2.28 & 18.87 & 14.15 & 0.53 & 1.95 & 2630.3 \\
III & 1.96 & 0.48 & 2.45 & 21.03 & 15.32 & 0.48 & 2.17 & 2735.5 \\
\hline
\end{tabular}

\section{Effect analysis of the fertilization model}

Studies have shown that crop yield and quality vary with different apply of fertilization (Wang et al., 2015). In recent years, in order to obtain higher yield, farmers usually apply excessive fertilizer, and the phenomenon of blind overfertilization is quite common. For instance, the current $\mathrm{N}$ fertilization rate for paddy fields of China is approximately $300 \mathrm{~kg} \mathrm{ha}^{-1}$, which exceeds the actual demand of rice growth (Chen et al., 2011; Xia and Yan, 2012). In most areas of China, the application of nitrogen and phosphate were too high, which affects the absorption of other nutrients (Zhang et al., 2010). The excess fertilizers will be lost to the surroundings through different pathways, including surface runoff, subsurface leaching and trace gas emissions, causing considerable environmental issues (Zhao et al., 2016).

Scientists have been actively searching for the best fertilization plan to promote continuous improvement of crop yield and quality. The fertilization model is one of the main methods of precision fertilization. Currently, the construction of a fertilization model mainly adopts a regression function model (Thompson et al., 2015), comprehensive fertilization models (Basso et al., 2016), and artificial neural network models (Alvarez and Steinbach, 2017). Each of the above methods has advantages but also has limitations. The regression function method determines the functional relationship between fertilization and yield or quality and usually does not consider the effect of basic soil fertility. The comprehensive fertilization model uses orthogonal design and orthogonal trends to analyse the fertilizer effect while the largest experimental workload used, and the error is difficult to control. The artificial neural network model requires a relatively large database, and the modelling cost is relatively high.

This study is a fertilization model based on the Truog-Stanford equation of the nutrient balance method. The fertilization amount of flue-cured tobacco recommended by this model is simple and effective. The yield of flue-cured tobacco was estimated in advance, and the best amount of fertilizer was calculated according to the fertilizer utilization rate and soil fertility correction coefficient. Sharma and Singh (2000) suggested that fertilizer recommendations based on targeted yield concept were more balanced, profitable and helpful in controlling soil nutrient mining and was essential for sustainable crop production. The verification tests showed that the model can help improving the formulation, balanced fertilizer management strategies in flued-cured tobacco. Such fertilizer management strategy will be more advantageous compared to conventional blanket and imbalanced fertilizer recommendation.

In this study, the amount of fertilizer recommended by the model was $30 \%$ less than the amount of conventional fertilization. In flue-cured tobacco planting, the application amount of $\mathrm{N}, \mathrm{P}_{2} \mathrm{O}_{5}$, and $\mathrm{K}_{2} \mathrm{O}$ fertilizer recommended by the model can decrease the input of fertilizer, reduce the production cost, and farmers can harvest more tobacco 
with less input. In addition, reducing the application of $\mathrm{N}, \mathrm{P}_{2} \mathrm{O}_{5}$, and $\mathrm{K}_{2} \mathrm{O}$ fertilizer can alleviate the soil pollution caused by excessive fertilization, and maintain the sustainable development of agricultural production. Therefore, the fertilization model obtained in this study plays a promoting role in flue-cured tobacco planting and can keep the health of ecological environment.

\section{Conclusion}

In this study, eight representative tobacco plots were selected in the mountainous area of southwest China for field experiments. Based on the Truog-Stanford equation of the nutrient balance method, the recommended flue-cured tobacco fertilization model was constructed. The fertilization models are $\mathrm{N}=0.091 \times Y-149.505 \times \mathrm{S}_{\mathrm{N}}{ }^{0.029} ; \mathrm{P}_{2} \mathrm{O}_{5}=$ $0.072 \times Y-11.595 \times \mathrm{SP}_{\mathrm{P}}^{0.749} ; \mathrm{K}_{2} \mathrm{O}=0.199 \times Y-55.924 \times \mathrm{S}_{\mathrm{K}}{ }^{0.351}$. The recommended fertilizer amount by the model was $30 \%$ less than the amount of conventional fertilization, and the model was reasonably feasible in the experimental area. The model in this study was closely related to the varieties of flue-cured tobacco and the basic soil fertility of the experimental plot. The verification and improvement of the model in more areas will be the focus of future studies.

Acknowledgments. This work was supported by the National Natural Science Foundation of China (31571621); and the Science and Technology Planning Project in Sichuan Province (2014RZ0026). We are very grateful to the College of Agronomy, Northwest A \& F University and School of Biological and Chemical Engineering, Panzhihua University for providing support. We also thank the editors and reviewers for their constructive comments during the preparation of the manuscript.

\section{REFERENCES}

[1] Ahmed, M., Rauf, M., Mukhtar, Z., Saeed, N. A. (2017): Excessive use of nitrogenous fertilizers: an unawareness causing serious threats to environment and human health. Environmental Science and Pollution Research 24: 26983-26987.

[2] Alvarez, R., Steinbach, H. S. (2017): Modeling Soil Test Phosphorus Changes under Fertilized and Unfertilized Managements Using Artificial Neural Networks. - Agronomy Journal 109: 2278-2290.

[3] Amankwa, G. A., Mishra, S., Shearer, A. D., Brammall, R., Van Hooren, D. L. (2014): CTH8 flue-cured tobacco hybrid. - Canadian Journal of Plant Science 94: 461-463.

[4] Basso, B., Liu, L., Ritchie, J. T. (2016): A Comprehensive Review of the CERES-Wheat, -Maize and -Rice Models' Performances. - Advances in Agronomy 136: 27-132.

[5] Chen, J., Huang, Y., Tang, Y. H. (2011): Quantifying economically and ecologically optimum nitrogen rates for rice production in south-eastern China. - Agriculture Ecosystems \& Environment 142(3-4): 195-204.

[6] Crossthwaite, A. J., Bigot, A., Camblin, P., Goodchild, J., Lind, R. J., Slater, R., Maienfisch, P. (2017): The invertebrate pharmacology of insecticides acting at nicotinic acetylcholine receptors. - Journal of Pesticide Science 42: 67-83.

[7] FAO/UNESCO. (1988): Soil Map of the World, Revised Legend. - FAO World Soil Resources Report No. 60, Rome.

[8] Gilhespy, S. L., Anthony, S., Cardenas, L., Chadwick, D., del Prado, A., Li, C. S., Misselbrook, T., Rees, R. M., Salas, W., Sanz-Cobena, A., Smith, P., Tilston, E. L., Topp, C. F. E., Vetter, S., Yeluripati, J. B. (2014): First 20 years of DNDC (DeNitrification DeComposition): Model evolution. - Ecological Modelling 292: 51-62. 
[9] Guillaume, S., Bruzeau, C., Justes, E., Lacroix, B., Bergez, J. E. (2016): A conceptual model of farmers' decision-making process for nitrogen fertilization and irrigation of durum wheat. - European Journal of Agronomy 73: 133-143.

[10] Hossain, S. A. A., Wang, L. X., Liu, H. S. (2018): Improved greenhouse cucumber production under deficit water and fertilization in Northern China. - International Journal of Agricultural and Biological Engineering 11: 58-64.

[11] Hu, W., Tian, S. B., Di, Q., Liu, J., Zhang, S. X. (2018): Nitrogen mineralization simulation dynamic in tobacco soil. - Journal of Soil Science and Plant Nutrition 18: 448465.

[12] Kumaresan, M., Rao, C. C., Reddy, D. D. (2019): Influence of drip fertigation on growth, yield and leaf-quality characters of suncured chewing tobacco (Nicotiana tobaccum). Indian Journal of Agronomy 64(3): 401-405.

[13] Lehmeier, C. A., Wild, M., Schnyder, H. (2013): Nitrogen Stress Affects the Turnover and Size of Nitrogen Pools Supplying Leaf Growth in a Grass. - Plant Physiology 162: 2095-2105.

[14] Li, D. F., Lu, X. X., Yang, X. K., Chen, L., Lin, L. (2018): Sediment load responses to climate variation and cascade reservoirs in the Yangtze River: A case study of the Jinsha River. - Geomorphology 322: 41-52.

[15] Lisuma, J., Mbega, E., Ndakidemi, P. (2020): Influence of Tobacco Plant on Macronutrient Levels in Sandy Soils. - Agronomy Basel 10(3): 30418.

[16] Pappa, V. A., Rees, R. M., Walker, R. L., Baddeley, J. A., Watson, C. A. (2011): Nitrous oxide emissions and nitrate leaching in an arable rotation resulting from the presence of an intercrop. - Agriculture Ecosystems \& Environment 141: 153-161.

[17] Russo, T. A., Tully, K., Palm, C., Neill, C. (2017): Leaching losses from Kenyan maize cropland receiving different rates of nitrogen fertilizer. - Nutrient Cycling in Agroecosystems 108: 195-209.

[18] Sharma, B. M., Singh, R. V. (2000): Fertilizer recommendations for wheat based on regression and targeted yield approaches: a comparison. - Journal of the Indian Society of Soil Science 48: 396-397.

[19] Sheets, L. P., Li, A. A., Minnema, D. J., Collier, R. H., Creek, M. R., Peffer, R. C. (2016): A critical review of neonicotinoid insecticides for developmental neurotoxicity. - Critical Reviews in Toxicology 46: 153-190.

[20] Shen, J. P., Zhang, L. M., Guo, J. F., Ray, J. L., He, J. Z. (2010): Impact of long-term fertilization practices on the abundance and composition of soil bacterial communities in Northeast China. - Applied Soil Ecology 46: 119-124.

[21] Shen, H., Shen, J. Z., Li, Y., Lai, Y. L., Jia, Z. H., Yi, J. H. (2017): Promotion of Lateral Root Growth and Leaf Quality of Flue-Cured Tobacco by the Combined Application of Humic Acids and Npk Chemical Fertilizers. - Experimental Agriculture 53: 59-70.

[22] Subhashini, D. V. (2016): Effect of N P K Fertilizers and Co-inoculation with PhosphateSolubilizing Arbuscular Mycorrhizal Fungus and Potassium-Mobilizing Bacteria on Growth, Yield, Nutrient Acquisition, and Quality of Tobacco (Nicotiana tabacum L.). Communications in Soil Science and Plant Analysis 47(3): 328-337.

[23] Sun, J. G., He, J. W., Wu, F. G., Tu, S. X., Yan, T. J., Si, H., Xie, H. (2011): Comparative Analysis on Chemical Components and Sensory Quality of Aging Flue-Cured Tobacco from Four Main Tobacco Areas of China. - Agricultural Sciences in China 10: 12221231.

[24] Sun, R. B., Zhang, X. X., Guo, X. S., Wang, D. Z., Chu, H. Y. (2015): Bacterial diversity in soils subjected to long-term chemical fertilization can be more stably maintained with the addition of livestock manure than wheat straw. - Soil Biology \& Biochemistry 88: 918.

[25] Thompson, L. J., Ferguson, R. B., Kitchen, N., Frazen, D. W., Mamo, M., Yang, H., Schepers, J. S. (2015): Model and Sensor-Based Recommendation Approaches for InSeason Nitrogen Management in Corn. - Agronomy Journal 107: 2020-2030. 
[26] Vann, M. C., Fisher, L. R., Jordan, D. L., Smith, W. D., Hardy, D. H., Stewart, A. M. (2013): Potassium Rate and Application Effect on Flue-Cured Tobacco. - Agronomy Journal 105: 304-310.

[27] Wang, X. J., Jia, Z. K., Liang, L. Y. (2015): Effect of straw incorporation on the temporal variations of water characteristics, water-use efficiency and maize biomass production in semi-arid China. - Soil \& Tillage Research 153: 36-41.

[28] White, F., Pandeya, R., Dirks, V. (1979): Correlation studies among and between agronomic, chemical, physical and smoke characteristics in flue-cured tobacco (Nicotiana tabacum L.). - Canadian Journal of Plant Science 59: 111-120.

[29] Williams, A., Manoharan, L., Rosenstock, N. P., Olsson, P. A., Hedlund, K. (2017): Long-term agricultural fertilization alters arbuscular mycorrhizal fungal community composition and barley (Hordeum vulgare) mycorrhizal carbon and phosphorus exchange. - New Phytologist 213: 874-885.

[30] Xia, Y. Q., Yan, X. Y. (2012): Ecologically optimal nitrogen application rates for rice cropping in the Taihu Lake region of China. - Sustainability Science 7(1): 33-44.

[31] Yavitt, J. B., Harms, K. E., Garcia, M. N., Mirabello, M. J., Wright, S. J. (2011): Soil fertility and fine root dynamics in response to 4 years of nutrient $(\mathrm{N}, \mathrm{P}, \mathrm{K})$ fertilization in a lowland tropical moist forest, Panama. - Austral Ecology 36: 433-445.

[32] Zhang, F., Niu, J. F., Zhang, W. F., Chen, X. P., Li, C. J., Yuan, L. X., Xie, J. C. (2010): Potassium nutrition of crops under varied regimes of nitrogen supply. - Plant and Soil 335(1-2): 21-34.

[33] Zhao, Z., Sha, Z. M., Liu, Y. B., Wu, S. H., Zhang, H. L., Li, C. S., Zhao, Q., Cao, L. K. (2016): Modeling the impacts of alternative fertilization methods on nitrogen loading in rice production in Shanghai. - Science of the Total Environment 566: 1595-1603. 